\title{
MINERALOGICAL AND GEOCHEMICAL FEATURES OF MAGNESIA-FERRUGINOUS CARBONATES OF THE AVZYAN ORE REGION OF THE SOUTHERN URAL IN CONNECTION WITH METASOMATHOSIS REGULARITIES
}

M. T. Krupenin, S. V. Michurin, A. A. Sharipova, T. Ya. Gulyaeva, V. G. Petrishcheva

\author{
Минерамогические и геохимические особенности магнезиаиьно- \\ железистых карбонатов Авзянского рудного района Южного Урала \\ в связи с закономерностями метасоматоза \\ М. Т. Крупенин, С. В. Мичурин, А. А. Шарипова, Т. Я. Гуляева, В. Г. Петришева
}

\begin{abstract}
$\triangle$ етальному минералого-геохимическому исследованию (термогравиметрический, рентгеноструктурный, химический анаииз и ICР-МS) подвергнуты магнезиамьно-железистые метасоматиты Авзянского рудного района, преАставленные железистыми магнезитами Исмакаевского месторожцения и брейнеритами проявления Богряшка. Метасоматиты приурочены к первично известняковой миньякской подсвите суранской свиты нижнего рисея. Железистые магнезиты содержат Ао 4 мас. \% FеО, брейнериты - Ао 20,5 мас. \% FеО, что подтвержАено расчетным методом по Аанным дисрактометрии. Установлены значимые корреляции между элементами группы железа и халькосильными элементами, отражаюшими их повышенные концентрации в широко прехставленном в метасоматитах пирите. Кроме того, отмечена сильная корреляция тория с легкими лантаноицами, обусловленная акцессорной вкрапленностью монацита. Корреляция карбонатных метасоматитов с их микроэлементным составом обозначается в связи доломита со стронцием, иттрием и лантаноидами средней-тяжелой группы (Sm-Lu). Выявлено три типа распределения редкоземельных элементов: Аоломитовый, магнезитовый и промежуточный, характеризующихся разным соотношением легких, средних и тяжелых лантаноидов в зависимости от положения в метасоматической колонке. Слабые положительные значения цериевой и европиевой аномалий в большинстве рассмотренных групп метасоматитов в определенной степени подтвержАают резко восстановительный характер флюицов. Геохимические Аанные совместно с анализом геологического строения и развития района позволяют связывать магнезиально-железистый метасоматоз в карбонатных породах суранской свиты с процессами ремобилизации захороненных в отложениях нижнего рисея эвапоритовых рассолов. Интенсивное взаимодействие рассолов с осацочными и вулканогенными породами в тектонически активной зоне Машакского ристогенного грабена привело к обогащению их различными лигандами, повышению основности и более активному гидротермальному переотложению в метасоматических продуктах лантаноицов средней и тяжелой группы.
\end{abstract}

Киючевые сиова: Аоломит; магнезит; брейнерит; метасоматизам; лантаноиды; рассолы.

The authors conducted a detailed mineralogical-geochemical study (thermogravimetric, X-ray diffraction, chemical analysis and ICP-MS) of the Magnesium-ferruginous metasomatites of the Avzyan ore region, represented by ferruginous magnesites of the Ismakaevo deposit and the brejnerites of the Bogryashka manifestation. Metasomatites are confined to the primarily limestone Minyak subsuite of the Suran Suite of the Lower Riphean. Iron magnesites contain up to $4 \%$ by weight of $\mathrm{FeO}$, braunerites - up to $20.5 \%$ by weight of $\mathrm{FeO}$, which the calculation method confirms according to diffractometry data. The authors established significant correlations between elements of the iron group and chalcophile elements, reflecting their increased concentrations in pyrite, widely represented in metasomatites. In addition, the authors noted a strong correlation of thorium with light lanthanides, which happens due to accessory impregnation of monazite. Correlation of carbonate metasomatites with their trace element composition appears in the interrelation of dolomite with strontium, yttrium and lanthanides of the middle-heavy group ( $\mathrm{Sm}-\mathrm{Lu}$ ). The article shows three types of distribution of rare-earth elements: dolomite, magnesite and mixed, characterized by a different ratio of light, medium and heavy lanthanides, depending on the position in the metasomatic column. Weak positive values of cerium and europium anomalies in most of the examined groups of metasomatites to some extent confirm the highly reducing nature of the fluids. Geochemical data together with the analysis of the geological structure and development of the region make it possible to associate magnesian-ferruginous metasomatism in the carbonate rocks of the Suran Suite with the processes of remobilization of evaporite brines buried in the Lower Riph ean deposits. Intensive interaction of brines with sedimentary and volcanogenic rocks in the tectonically active zone of the Mashak riftogenic graben resulted in thei enrichment with various ligands, increase in basicity and more active hydrotherma redeposition in the metasomatic products of the lanthanides of the middle and heavy groups.

Keywords: dolomite; magnesite; breinerite; metasomatism; lanthanides; brines.

ntroduction

Certain important to the industry minerals are carbonate magnesian-ferruginous metasomatites. From magnesite with complete roasting, one can obtain periclase, which is the main refractory material for modern metallurgy, while caustic (lightly roasted) magnesite is the base for the production of special cements. Siderite is a valuable iron ore, which has a minimum amount of bad impurities.
Minerals of the magnesite-siderite series also are among the natural metasomatic formations: ferrous magnesite (breinerite), as well as ferruginous dolomite (ankerite), are a substrate for the formation of iron ore deposits of residual weathering crust. The relevance of determining the conditions for the formation of magnesian-ferruginous carbonates fits into the widely discussed fundamental problem of the formation of epigenetic carbonates, including dolomite, magnesite, ankerite and siderite in limestone strata.

Magnesian-ferruginous metasomatites in the Southern Urals are widely developed in Riphean deposits, the total thickness of which exceeds $15 \mathrm{~km}$. Carbonate deposits are developed in the upper parts of all three sedimentary series of Riphean and are confined to the structure of the Bashkir meganticlinorium (BMA) [1]. They mainly contain shallow-water shelf limestones, less often horizons of early diagenetic evaporite dolomites.

Among the carbonate metasomatites in the Riphean section, two groups stand out: magnesian and magnesian-ferruginous. The first group includes dolomites and magnesites. Dolomites under the formation conditions are divided into early diagenetic (the result of dolomitization in the evaporite sedimentation basin), metasomatic catagenetic and hydrothermal in tectonic filling veins. Magnesites are relatively early metasomatites, developing on diagenetic dolomites and limestones, in the latter case magnesites locate into the "envelope" of metasomatic dolomites. Magnesian-ferruginous carbonates, in comparison with magnesites, usually belong to later formations. Among them, there are three types: ankerites, breinerites and siderites, each of which has a predominantly metasomatic origin, but also there are hydrothermal filling veins.

The authors detaily investigated the magnesian-ferruginous metasomatites of the Avzyan ore region. Metasomatites are located in the primarily limestone Minyak subsuite of the Suran Suite. The Suran Suite of the Lower Riphean has a form of submeridional strip, 


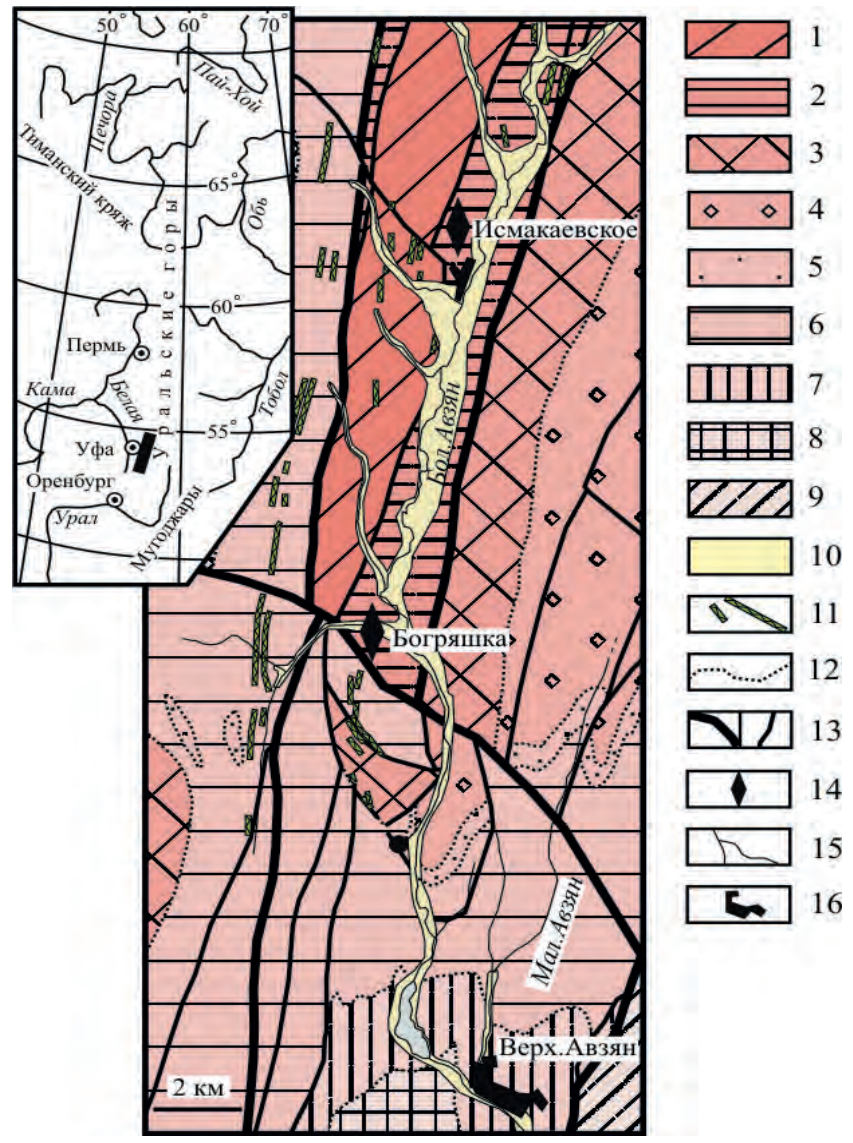

Figure 1. Geological scheme of the southern part of the Bashkir meganticlinorium (according to [5]) and the position of the Ismakaevo magnesite deposit and the Bogryashka ore occurrence. 1-3 - sediments of the Lower Riphean, suites: 1 - Bolsinzer, 2 - Suran, 3-Yusha; 4-7 - deposits of the Middle Riphean, suites: 4 - Mashak, 5 - Zigalga, 6 - Zigazino-Komarovo, 7 - Avzyan; 8-9 - deposits of the Upper Riphean, suites: 8 - Zilmerdak, 9 - Minyar; 10 Quaternary sediments; 11 - dikes of igneous rocks; 12 - the boundaries of the suites; 13 - tectonic disturbances of different orders; 14 - Ismakaevo deposit of magnesite and Bogryashka ore occurrence; 15 - rivers; 16 - settlements.

is located in the western part of the Yamantau anticlinorium of the BMA, and spatially coincides with the valley of the river B. Avzyan (Fig. 1). Limestones of the Minyak subsuite are intensely dolomitized; in addition, metasomatic dolomites contain several ore objects. $20 \mathrm{~km}$ to the north of the Verkhny Avzyan village there is a large Ismakayevo deposit of sparry magnesites (in the area of the village with the same name). $10 \mathrm{~km}$ to the south of Ismakaevo village, where the Bogryashka stream flows into the river B. Avzyan, drilling revealed a potent zone of breinerite metasomatites. $22 \mathrm{~km}$ to the north of Ismakaevo village, in the same zone of the dolomites of the Minyak subsuite of the Suran Suite, there is the Suran fluorite deposit and several points of fluorite mineralization in the host dolomites.

Research Methods

The authors performed X-ray diffraction analysis on a XRD7000 diffractometer (Shimadzu) in the IGG UB RAS in filtered copper radiation. The authors obtained diffractograms on powder samples in the region of Bragg angles $4-65^{\circ}$, and then determined their mineral composition. For all the samples of studied carbonate rocks, the authors calculated the $\mathrm{FeO}$ content in magnesite and dolomite. For magnesites, this study determined the value of the interplanar distance $d_{104}$, the most intense and most sensitive to isomorphism of $\mathrm{Fe}-\mathrm{Mg}$ reflex (for its third order, $\mathrm{d}_{30.12}$ ). Recording was carried out in Bragg angles of $113-116^{\circ}$ at a rate of $0.25^{\circ} / \mathrm{min}$. Then, according to the graph of the dependence of the value of $\mathrm{d}_{104}$ on the $\mathrm{FeCO}_{3}$ content for the magnesite-siderite series [2], the authors calculated the amount of percent by mole of $\mathrm{FeCO}_{3}$ in magnesites, and then recalculated it for $\mathrm{FeO}$. For dolomites, determination of the content of $\mathrm{FeO}$ was made via the 633 reflex (3.0.12) - the third order of the most intense and most sensitive to the isomorphism $\mathrm{Fe}-\mathrm{Mg}$ series 104 . Recording was carried out in Bragg angles of $105-107^{\circ}$ at a rate of $0.25^{\circ} / \mathrm{min}$. According to the graph of the dependence of the interplanar distance $d_{633}$ on the $\mathrm{FeO}$ content in the dolomite [3], one can be calculate the amount of ferrous iron in the studied dolomites, which happens to be $0-1 \%$.

Thermogravimetric analysis (TGA) determined the mineral composition of samples of thermally non-inert minerals on the Diamond TG / DTA (Perkin Elmer) derivatograph at the IGG UB RAS. The error in determining of the change in mass was $\pm 0.1 \%$; the error in determining of the temperature of the peaks was $\pm 0.3{ }^{\circ} \mathrm{C}$. The authors used reference curves from literature data [4] for the quantitative calculations. The error in determining of the clay minerals was $\pm 5 \%$, others $\pm 1 \%$.

$\mathrm{X}$-ray fluorescence analysis was carried out for determination of the chemical composition of the samples on a VRA-30 spectrometer (Karl Zeiss, Germany) in the IG UC RAS (Ufa) using an X-ray tube with a Cr-anode $(30-40 \mathrm{kV}, 30 \mathrm{~mA})$. Powdered samples weighing $5 \mathrm{~g}$ with a binder (5 drops of PVS-8) were pressed at a pressure of 25-27 tons on a substrate of boric acid. The detection limit for the measurement of $\mathrm{SiO}_{2}, \mathrm{Al}_{2} \mathrm{O}_{3}$ was $0.1 \%$; $\mathrm{TiO}_{2}, \mathrm{Fe}_{2} \mathrm{O}_{3}, \mathrm{MnO}, \mathrm{CaO}, \mathrm{K}_{2} \mathrm{O}, \mathrm{P}_{2} \mathrm{O}_{5}$, $\mathrm{S}_{\text {general }}-0.01 \% ; \mathrm{MgO} 0.2 \% ; \mathrm{Na}_{2} \mathrm{O}-0.5 \% ; \mathrm{Cl}-0.002 \%$.

Analysts N. V. Cherednichenko and D. V. Kiseleva performed the measurements of minor elements concentrations in carbonate rocks using the ICP-MS method on ELAN-9000 (Perkin Elmer) in the IGG UB RAS using the standard method for silicate rocks with indium as a reference element.

Research results

Ismakayevo magnesite deposit. The Ismakayevo deposit has more than 100 million tons of magnesite reserves [6]. The magnesite deposit has a very complicate structure and practically is a series of lenticular bodies separated by interlayers of phyllitic schists and dolomites. Its total thickness reaches $400 \mathrm{~m}$, its length is $1100 \mathrm{~m}$, and its dip is about $800 \mathrm{~m}$. The magnesite mineralization, as well as the dolerite sill in its lower part, repeats all the plicative structures of the deposit, which indicates the prefolded type of both formations.

Metasomatic contacts of magnesite bodies with host dolomites represent a zone with a thickness of up to the first meters of crystals impregnation with sizes up to 1-2 millimeters, in fine-grained dolomites (grain size up to $0.2-0.5 \mathrm{~mm}$ ). The research allowed to trace dolomites along the carbonate horizon for up to $500 \mathrm{~m}$ in the north direction, where, inconsistent with the bedding of rocks, appears a zone of dolomite transition into fine-grained limestones with patches of pelitomorphic limestones [7]. Lateral metasomatic zonation for the Ismakaevo deposit from the rear to the frontal zone is as follows: magnesite-dolomite with dissemination of magnesite-dolomite-dolomitized limestone-limestone. In the mineral composition of the zones, diffractometry and microscopic study established a number of characteristic minerals-impurities. In magnesite, it is dolomite and quartz, chlorite, and sometimes an accessory admixture of albite, muscovite, more rarely talc. In the dolomitized limestones, potassium feldspar is always present together with quartz, muscovite, and sometimes with albite. With the development of metasomatism, muscovite replaces potassium feldspar in the dolomite, and chlorite replaces muscovite in magnesite.

Magnesite is of medium crystalline size, the size of granoblast grains is $1-5 \mathrm{~mm}$, magnesite crystals are rarely found up to $20 \mathrm{~mm}$, with a constant admixture of dolomite (2-5\%), nests and dissemination of quartz (10-15\%), small pyrite cubes, interstitial inclusions of magnesia chlorite (1-5\%), sericite, rarely microinclusions of talc.

The characteristic features of chemical composition of magnesites are an increased content of $\mathrm{CaO}, \mathrm{SiO}_{2}, \mathrm{Al}_{2} \mathrm{O}_{3}$ and corresponds to the increased contents of the aluminosilicate impurity in the host carbonate rocks. There is a high background of iron content in magnesite at $2.8-4.5 \%$ of $\mathrm{Fe}_{2} \mathrm{O}_{3}$ at $\mathrm{MgO}$ concentrations of $37-42.5 \%$. Increased 

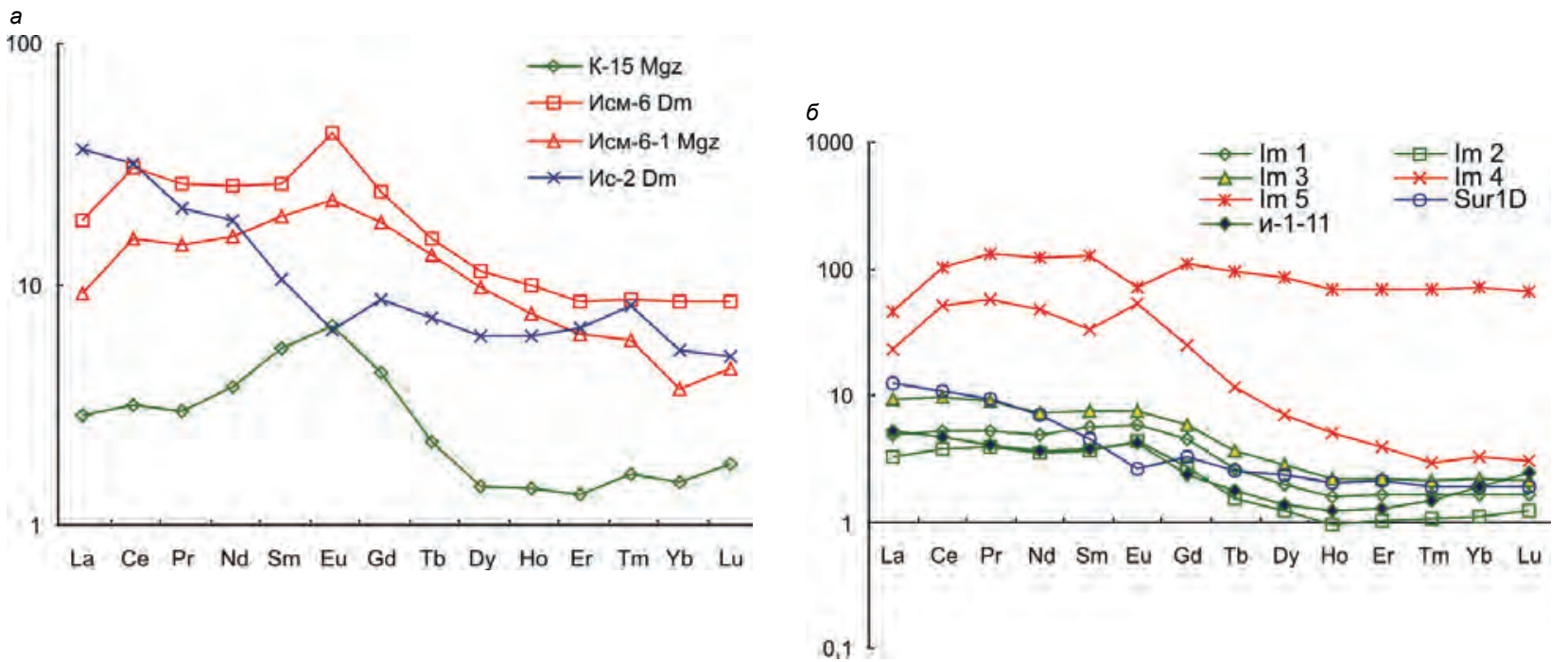

Figure 2. Chondrite-normalized (C1) distribution of REE in remote (blue), near-ore (red color) dolomites and magnesites (green) of two parts (a, b) of the Ismakaevo deposit.

iron concentrations at $1.00-3.44 \%$ of $\mathrm{Fe}_{2} \mathrm{O}_{3}$ are also characteristic for metasomatic dolomites, both for near-ore deposits and at the front of metasomatism, near the contact with limestones [7].

The distribution of microelements in magnesite according to ICP-MS in comparison with dolomites has reduced concentrations of almost all elements, primarily strontium, yttrium and rare earth elements (REE). The distribution of REE in the dolomites and magnesites differs from other deposits in the South Ural province by the presence of a positive anomaly of europium (Fig. $2, a, b$ ). In addition, in the wallrock dolomites there is a general increase in REE concentrations relative to the host carbonate rocks and a change in the general pattern of distribution with a roof-like increase of lanthanides of the middle group (from Gd to Ho). The magnesites of Ismakayevo deposit have a low Y/Ho ratio (24), in limestones it gradually increases to 35 [8], which may indicate a significant migration range of hydrothermal solutions during metasomatism [9].

According to the study of Sm-Nd systematic, the average value of epsilon Nd (calculated for $1550 \mathrm{Ma}$ ) for the limestones and dolomites of the Suran Suite is -6.5 , which is close to the value of epsilon $\mathrm{Nd}-7.3$ for the shales of the Satka Suite of the same stratigraphic level of the Lower Riphean [10]. The values of epsilon $\mathrm{Nd}_{(1250)}$ in magnesites from -11.3 to -9.0 indicate the crustal nature of the metasomatic fluid. The errochronous Sm-Nd magnesite age value of $1250 \pm 130 \mathrm{Ma}$ [11] has a geological meaning, since in the given region the scientists earlier dated fluorites of the Suran deposit in the dolomites of the Suran suite with the age of $1230 \mathrm{Ma}$ using Sm-Nd and $\mathrm{Rb}-\mathrm{Sr}$ methods [12]. The $\mathrm{Cl}-\mathrm{Br}-\mathrm{Na}$ data (ion chromatography) of fluid inclusions in magnesites and host dolomites of the Ismakaevo deposit show the evaporite nature of the ore fluid. Microcryometry methods also confirm very high salinity of the two-phase inclusions in magnesites (average value $23.6 \%$ by weight of $\mathrm{NaCl}$ equivalent). The homogenization temperatures fit into the interval of $184-279^{\circ} \mathrm{C}$ with an average value of 224 ${ }^{\circ} \mathrm{C}[13]$.

Breinerite metasomatites of the Bogryashka ore occurrence. The Bogryashka ore occurrence is located in the valley of the river of the same name, $10 \mathrm{~km}$ to the north of the village V. Avzyan. It is a zone of metasomatically transformed dolomites of the Minyak subsuite of the Lower Riphean Suran Suite. Researchers opened the zone of metasomatites by wells in 1975-1982 near the old quarry for the mining of gold-bearing placers. The thickness of the zone of carbonate metasomatites from drilling data is about $70 \mathrm{~m}$; it has a traced depth of 313.5 $\mathrm{m}$ and a length of $400 \mathrm{~m}$ (Fig. 3). Ore metasomatites mainly consist of ferruginous magnesites (breinerites), which contain gold-bearing nest-vein sulfide mineralization. The gold content in metasomatites is low, $0.2-0.8 \mathrm{~g} / \mathrm{t}$ in average. Gold is due to sulfides and does not present industrial interest.

Structurally, the ore occurrence is in a block of rocks, sandwiched between two regional discontinuous structures - the Karatash and Bolsheavazyan fractures, at the area of their closest rapprochement. It is located in the core of the Bolsheavazyan anticline, entangled by numerous small folds and disruptive disturbances of the northwestern and northeastern directions. In the valley of the river Bogryashka, through the central part of the ore occurrence, there is a discontinuous disruption of the sublatitudinal direction. Shtock-like bodies of carbonate metasomatites occur at the intersection of discontinuous disruptions of the sublatitudinal and northwestern strike. In general, the zone of carbonate iron-magnesian metasomatites has a NW-SE stretch.

Magmatic formations within the area of ore occurrence are represented by a series of dikes of the hornblende diabases and gabbro-diabases of the Lapishta complex, which belongs to the Middle Riphean formations [14]. Dikes develop along discontinuous disturbances of the northeastern direction. The thickness of the dikes reaches $5 \mathrm{~m}$; their decline is steep east at an angle of $70-80^{\circ}$. Hornblende diabases and gabbro-diabases undergone an intense metamorphose and, in some places, a complete conversion to carbonate-sericite-chlorite rocks. From the east, the volcano-terrigenous formations of the Mashak riftogenic complex, formed at the beginning of the Middle Riphean (the age of volcanics is about $1380 \mathrm{Ma}$ ), were thrusted over the Lower Riphean deposits [15]. In addition, approximately 1.5-2 $\mathrm{km}$ to the south-south-east of the ore occurrence in the sediments of the Mashak Suite according to the results of geophysical studies researchers found a powerful body of diabases, attributed to the Mashak formations.

The $\mathrm{Mg}-\mathrm{Fe}$ metasomatites consist of rhombohedral granules, up to $1.5 \mathrm{~mm}$ in size, on the background of fine-small-crystalline enclosing dolomites of the Minyak subunit of the Suran suite, and in this respect resemble the granoblastic medium-grained magnesites of the Ismakaevo deposit. Metasomatites have a polymineral composition with a variable content of $\mathrm{Fe}$-magnesite (breinerites from 10 to 93\%) and dolomite (from 2 to $90 \%$ ), as well as varying, sometimes significant amounts of pyrite (up to 20\%), quartz (up to 10\%), muscovite (up to $4 \%)$ and rarely chlorite. There was no definite dependence in the distribution of breinerite and dolomite. Using the method of calculating the iron in breinerites (the X-ray method), the authors found that the content of isomorphous iron varies within wide limits - from 5-6 


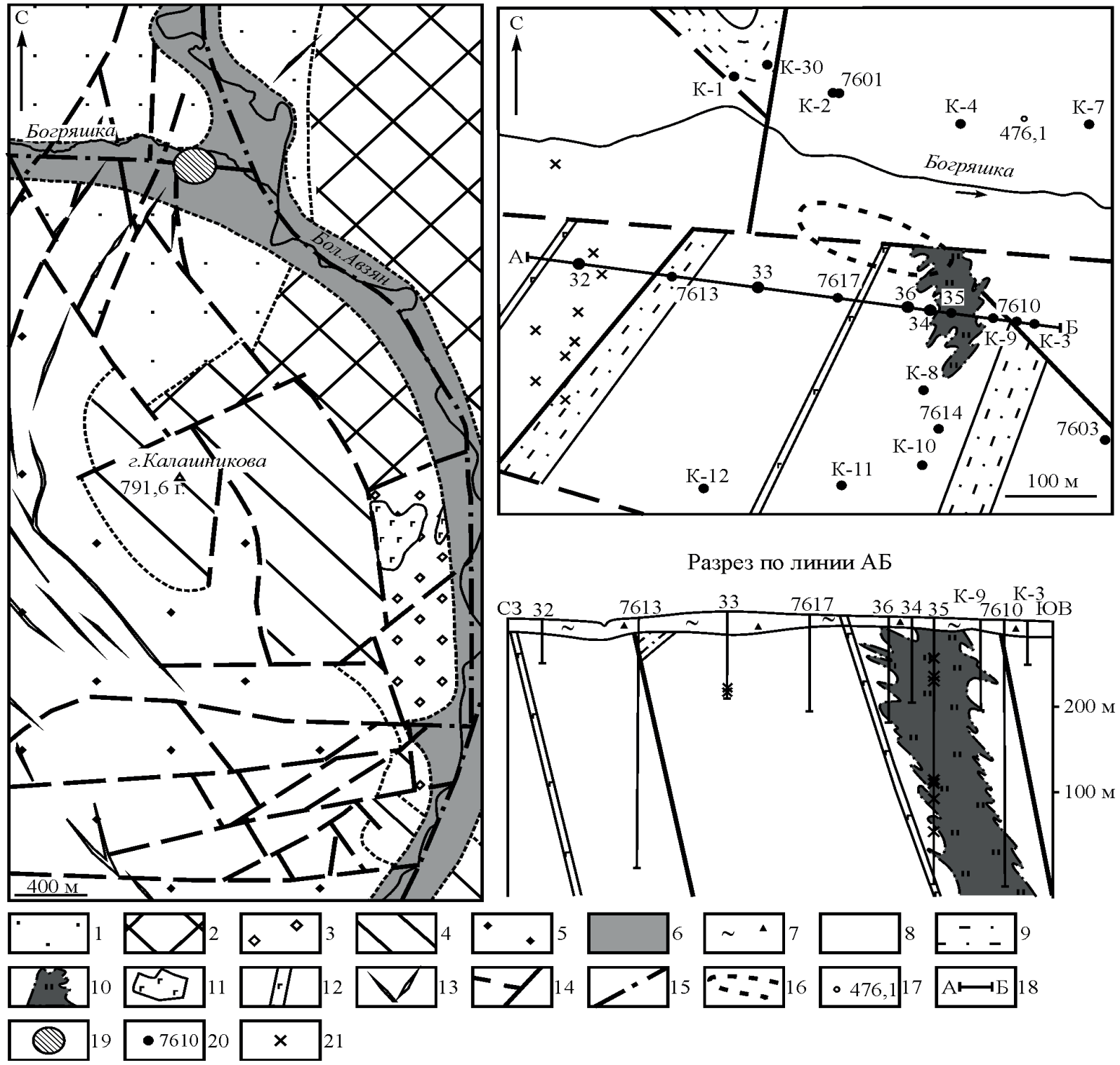

Figure. 3. Geological scheme and section of the Bogryashka ore occurrence (based on the materials of the Abzelilovskaya GPP) and the locations of sampling points. 1-2 - sediments of the Lower Riphean, suites: 1 - Suran, 2 - Yusha; $3-5$ - sediments of the Middle Riphean, suites: 3 - Mashak, 4 - Zigalga, 5 - Zigazino-Komarovo; 6 - Quaternary sediments; 7 - weathering crust; 8-9-deposits of the Minyak subsuite of the Suran suite: 8 - dolomites, 9 - interbedding of sandstones, siltstones and low-carbon clay shales; 10 - zone of gold ore metasomatites; 11 - diabase and diabase porphyrites; 12 - gabbro-diabase dikes; 13 dikes of basic composition, isolated according to magnetic prospecting data; 14 - tectonic disturbances; 15 - latent tectonic disturbances; 16 - quarry for processing alluvial gold; 17 - topographic heights; 18 - section line; 19 - Bogryashka ore occurrence; 20 - wells and their numbers; 21 - sampling points for geochemical study.

to $18-20.5 \%$ by weight of $\mathrm{FeO}$ (see Table 1 ). As a rule, the higher the amount of the mineral phase of breinerite in the sample, the higher the iron content in the breinerite itself. Determination of iron in the dolomite phase by the X-ray method showed low values, at the level of $1-2 \%$ by weight of $\mathrm{FeO}$.

In three samples of dolomite during the thermal analysis, anomalous patterns of dissociation appeared. In the majority of samples the dolomite dissociates with the formation of two endothermic peaks at temperatures of $770-800{ }^{\circ} \mathrm{C}$ and $830-870{ }^{\circ} \mathrm{C}$, but dissociation in samples A-12341, A-12346, A-12348 happened stepwise at 740-780, 800-900 and $975-1015{ }^{\circ} \mathrm{C}$. In addition, in the sample A-12341 were endothermic peaks at $124-206{ }^{\circ} \mathrm{C}$ with a weight loss of $3.8 \%$. After washing in boiling distilled water, these peaks, both low-temperature and high-temperature, disappeared, and the dissociation pattern became similar to dolomite. We assume that the anomalous pattern of dissociation of dolomite is due to the presence of the thrones (natural soda) and evaporite minerals (halite, mirabilite), analogous to the dissociation curves of dolomites from the evaporite basins considered in the monograph of Tsvetkov A. I. et al. [4]. At the same time, according to the results of X-ray fluorescence analysis in the samples of dolomites and magnesites low chlorine contents were at the level of $0,01-0,03 \%$ by mass, while magnesites had the maximum noted values [15].

According to the chemical composition, a part of the carbonate metasomatites match with breinerites, a variant of ferruginous magnesite, a member of the isomorphous magnesite-siderite series, in which the $\mathrm{FeCO}_{3}$ content can reach $30 \mathrm{wt} . \%$. In ore metasomatites (Table 2, samples A-12341-A-13479, $\mathrm{Br}_{\text {bog }}, \mathrm{Br}_{\text {bog }}{ }^{*}$ ), the content of iron and magnesium sharply increases in comparison with the host dolomites. In the $\mathrm{Br}_{\text {bog }}$ and $\mathrm{Br}_{\text {bog }}{ }^{*}$ samples, the $\mathrm{FeO}$ content is $6.91-12.24 \%$ by weight, with a high $\mathrm{MgO}$ content $(33.45-37.1 \%$ by weight) and an insignificant $\mathrm{CaO}(0.28-2.0 \%$ by weight) (See Table 2$)$, which is typical for breinerites. Some of the samples of ore metasomatites are chemically close to the magnesites of the Ismakaevo deposit - magnesite is enriched with silica with a low content of alumina and relatively high iron content (see Table 2, A-13479). At the same time, the difference between the Bogryashka breinerites from Ismakayevo magnesites, along with the high contents of isomorphic iron, is the presence of increased concentrations of several generations of pyrite. 
Table 1. Mineral composition of carbonate iron-magnesian metasomatites of Bogryashka, mass \%.

\begin{tabular}{|c|c|c|c|c|c|c|c|c|c|c|c|}
\hline № & № sample & Brnt & Dol & Cal & Py & Qz & Chl & Ms & $\mathrm{OB}$ & Summary & $\begin{array}{c}\mathrm{FeO}, \% \text {, } \\
\text { in Brnt }\end{array}$ \\
\hline 1 & A-12341 & 76 & 2 & - & 1 & 5 & - & 1 & Urao 13-16 & $97-100$ & 9 \\
\hline $1-1$ & $\begin{array}{l}\text { Washed from } \\
\text { urao and halite }\end{array}$ & 85 & 4 & - & 1 & 6 & - & 1 & - & 97 & 9 \\
\hline 2 & A-12342 & 75 & 23 & - & 2 & Low & - & - & - & 100 & 20,5 \\
\hline 3 & A-12344 & 85 & 14 & - & 0,5 & - & - & - & 0.5 & 100 & 16,5 \\
\hline 4 & A-12345 & 69 & 29 & - & 2 & - & - & - & - & 100 & 18,5 \\
\hline 5 & $A-12345 c$ & 10 & 89 & - & 1 & - & - & - & - & 100 & - \\
\hline 6 & A-12346 & 75 & 10 & - & Up to 15 & - & - & - & - & 100 & 18,5 \\
\hline 7 & A-12346a & 50 & 30 & - & Up to 20 & - & - & - & - & 100 & $5-6$ \\
\hline 8 & A-12347 & 25 & 45 & - & Up to 20 & Low & - & - & - & 90 & 2 \\
\hline 9 & A-12348 & 35 & 25 & - & Up to 20 & - & - & - & - & 80 & 13,5 \\
\hline 10 & А-12348л & 11 & 80 & - & 8 & - & - & - & - & 99 & - \\
\hline 11 & A-12349 & 68 & 32 & - & 1 & - & - & - & - & 100 & 18,5 \\
\hline 12 & A-12350 & 80 & 2 & - & 1 & 13 & - & 3 & - & 99 & $5-6$ \\
\hline 13 & A-12352 & 86 & 4 & - & - & 4 & - & 4 & - & 98 & $8-9$ \\
\hline 14 & A-13478 & - & 90 & - & - & 10 & - & - & - & 100 & - \\
\hline 15 & A-13479 & 93 & 2 & Low & - & Low & 3 & 1 & Low & - & $4-5$ \\
\hline
\end{tabular}

Notes: Brnt - ferrous magnesite (breynerite); Dol - dolomite; Cal - calcite; Py - pyrite; Qz - quartz; Chl - chlorite; Ms - muscovite; OM - an organic matter; FeO,\%, in Brnt - the iron content in the brenerite according to X-ray diffraction analysis.

The most widespread pyrite is the one considerably enriched with the ${ }^{34} \mathrm{~S}$ isotope. The average value of $\delta^{34} \mathrm{~S}$ is $16.1 \%$ o $(n=25)$ with a dispersion of values from 7.9 to $27.4 \%$ [16]. It is important to note that such variations in the values of $\delta^{34} S$ completely correspond to the isotope composition of sulfur from pyrite, occurring as impregnation in the sedimentary rocks of the Suran Suite [17]. From the position of isotope geochemistry, the source of sulfur in the formation of such a pyrite strongly enriched with heavy ${ }^{34} \mathrm{~S}$ isotope is most likely the sulphates of evaporites.

Data from the study of the magnesian-ferruginous metasomatites of the Bogryashka ore occurrence using the ICP-MS method for 50 elements showed no anomaly contents, except for individual high concentrations of arsenic (sample A-12344, $1508 \mathrm{~g} / \mathrm{t}$ ), antimony (sample A-12346a, 15,8 g/t) and lead (samples A-12346a and A-12348, up to $22 \mathrm{~g} / \mathrm{t}$ ). Consideration of the correlation matrix of the contents of all microelements made it possible to establish significant correlations between the elements of the iron group $(\mathrm{Fe}, \mathrm{Co}, \mathrm{Ni})$ and chalcophile elements $(\mathrm{Cu}, \mathrm{Zn}, \mathrm{Pb}, \mathrm{Bi}, \mathrm{Tl}, \mathrm{Cd}, \mathrm{Ag}, \mathrm{Sb}, \mathrm{Ba})$ reflecting their increased concentrations in widely represented in metasomatites pyrite. In addition, the authors established an important correlation (0.83-0.86) of thorium with light lanthanides ( $\mathrm{La}, \mathrm{Ce}, \mathrm{Pr}, \mathrm{Nd}$ ). Detailed mineralogical study of some samples by the microprobe method showed that they contain an accessory impregnation of monazite. The content of thorium in the examined samples according to ICP-MS data reaches $2.8 \mathrm{~g} / \mathrm{t}$ (sample A-12347). A stable correlation of yttrium (0.91-0.99) and strontium $(0.58-0.78)$ with heavy lanthanides $(\mathrm{Sm}-\mathrm{Lu})$ is also sig- nificant. Of the not quite normal relationships, a very high correlation (0.94) between Th and $\mathrm{Cr}$ is worth noting.

One can see a more definite picture for finding correlation of the mineral composition of carbonate metasomatite samples with their trace element composition (Table 3). Here, the connection of dolomite with strontium and yttrium is clear, as well as with the lanthanides of the middle-heavy group ( $\mathrm{Sm}-\mathrm{Lu}$ ). In ferruginous magnesites, there is no fixed sufficiently stable correlation between any elements; even manganese has a correlation coefficient of 0.43 , despite its known affinity for iron. At the same time, there is a stable connection of pyrite with chalcophile elements and sulfosalts. Quartz and muscovite have clear connections with rare lithophilic elements and at the same time, the authors note a weak correlation (0.26-0.38) of these minerals with light lanthanides (La, Ce, Pr).

The distribution of REE in the carbonate metasomatites of ore shows a rather complex picture (Fig. 4). Here the authors distinguish the following types of trends: (1) the distribution is similar for magnesites of the Ismakaevo deposit (sample A-13479, see Fig. 4, a), (2) the distribution is similar for Ca-containing minerals (in particular, dolomites, sample A-13478, see Fig. 4, a); (3) a distribution is similar for the wallrock dolomites of the Ismakaevo deposit with a "roof-like" distribution in the region of medium-composition lanthanides (see Fig. $4, b$ ). The pure magnesites, to which the sample A-13479 belongs, have a relative decrease in the concentrations of lanthanum and cerium and an increase in the concentrations of heavy lanthanides.
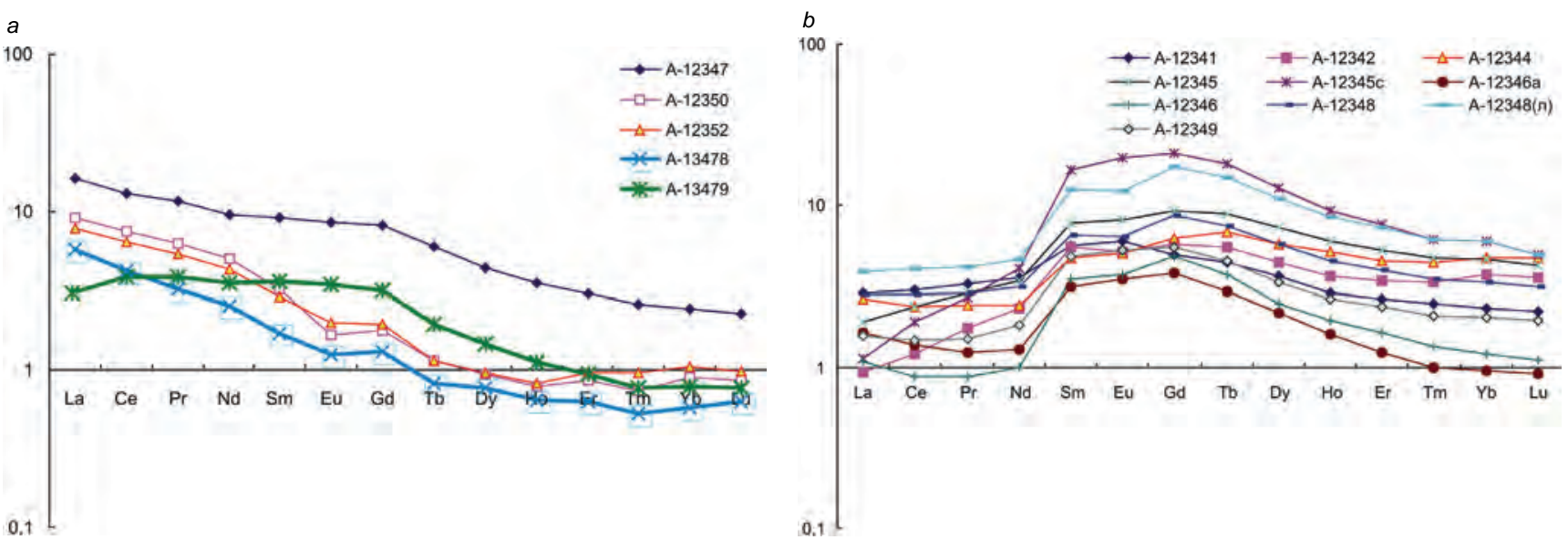

Figure 4. Chondrite-normalized (C1) distribution of REE in the carbonate metasomatites of Bogryashka (sample numbers correspond to those in Table 1). $a$ - for Ca-containing minerals and magnesites, for comparison, table shows pure dolomite A-13478 and pure magnesite A-13479; $b$ - distribution similar for the dolomites of the Ismakaevo deposit. 
Table 2. Chemical composition of the carbonate rocks of the ore formation of Bogryashka.

\begin{tabular}{|c|c|c|c|c|c|c|c|c|}
\hline № & № sample & $\mathrm{SiO}_{2}$ & $\mathrm{TiO}_{2}$ & $\mathrm{Al}_{2} \mathrm{O}_{3}$ & $\mathrm{Fe}_{2} \mathrm{O}_{3}$ & $\mathrm{FeO}$ & $\mathrm{CaO}$ & $\mathrm{MgO}$ \\
\hline 1 & $\mathrm{Dl}_{\text {sur1 }}$ & 8,91 & 0,06 & 1,42 & 0,34 & 1,49 & 27,84 & 18,38 \\
\hline 2 & $\mathrm{DI}_{\mathrm{bog}}$ & 2,67 & - & 0,14 & 0,50 & 4,71 & 26,18 & 20,34 \\
\hline 3 & A-12341 & 4,82 & 0,07 & 0,49 & 11,58 & - & 2,73 & 33,27 \\
\hline 4 & A-12342 & 0,84 & 0,02 & $<0,1$ & 15,08 & - & 12,80 & 24,04 \\
\hline 5 & A-12344 & 0,54 & 0,01 & $<0,1$ & 14,68 & - & 10,07 & 28,82 \\
\hline 6 & A-12345 & 0,71 & 0,01 & $<0,1$ & 12,26 & - & 15,63 & 26,29 \\
\hline 7 & A-12346a & 0,87 & 0,02 & $<0,1$ & 28,41 & - & 9,49 & 15,27 \\
\hline 8 & A-12348 & 5,88 & $<0,01$ & 1,00 & 15,00 & - & 12,36 & 10,15 \\
\hline 9 & A-12349 & 0,59 & 0,01 & 0,10 & 12,55 & - & 15,23 & 25,73 \\
\hline 10 & A-12350 & 10,95 & 0,08 & 0,82 & 9,95 & - & 1,28 & 34,17 \\
\hline 11 & A-12350* & 13,5 & 0,06 & 1,20 & 4,34 & 2,94 & 0,8 & 34,86 \\
\hline 12 & A-12352 & 5,21 & 0,05 & 0,80 & 13,02 & - & 2,73 & 31,84 \\
\hline 13 & A-12352* & 5,00 & 0,02 & 0,70 & 7,21 & 3,93 & 1,14 & 35,98 \\
\hline 14 & A-13478 & 4,44 & 0,03 & 0,74 & 1,99 & - & 33,37 & 18,48 \\
\hline 15 & A-13479 & 1,61 & 0,05 & 0,41 & 6,46 & - & 1,70 & 41,34 \\
\hline 16 & $\mathrm{Br}_{\text {bog }}$ & 7,48 & 0,03 & 0,82 & 0,73 & 6,91 & 0,28 & 37,10 \\
\hline 17 & $\mathrm{Br}_{\text {bog }^{*}}$ & 6,16 & - & 0,65 & 0,71 & 12,24 & 2,0 & 33,45 \\
\hline № & № sample & $\mathrm{MnO}$ & $\mathrm{P}_{2} \mathrm{O}_{5}$ & $\mathrm{~K}_{2} \mathrm{O}$ & $\mathrm{Na}_{2} \mathrm{O}$ & $\mathrm{S}_{\text {gen }}$ & $\begin{array}{c}\text { Lost } \\
\text { of ignitions }\end{array}$ & Summary \\
\hline 1 & $\mathrm{DI}_{\text {sur1 }}$ & 0,06 & 0,05 & 0,08 & 0,10 & - & 41,21 & 100,66 \\
\hline 2 & $\mathrm{DI}_{\mathrm{bog}}$ & 0,19 & - & - & - & - & 45,06 & 99,79 \\
\hline 3 & A-12341 & 0,34 & 0,03 & 0,27 & 0,13 & 2,77 & 43,23 & 99,74 \\
\hline 4 & A-12342 & 0,50 & 0,04 & $<0,01$ & 0,14 & 1,47 & 44,45 & 99,37 \\
\hline 5 & A-12344 & 0,42 & 0,03 & $<0,01$ & 0,12 & 0,52 & 44,46 & 99,70 \\
\hline 6 & A-12345 & 0,38 & 0,05 & $<0,01$ & 0,11 & 1,31 & 42,40 & 99,16 \\
\hline 7 & A-12346a & 0,07 & 0,05 & $<0,01$ & 0,13 & 21,14 & 23,65 & 99,10 \\
\hline 8 & A-12348 & $<0,01$ & $<0,01$ & 0,10 & 0,12 & - & 31,16 & 75,77 \\
\hline 9 & A-12349 & 0,43 & 0,04 & $<0,01$ & 0,12 & 0,29 & 43,95 & 99,05 \\
\hline 10 & A-12350 & 0,30 & 0,05 & 0,41 & $<0,1$ & 0,52 & 41,15 & 99,66 \\
\hline 11 & A-12350* & 0,16 & 0,03 & 0,41 & 0,24 & - & 41,20 & 99,74 \\
\hline 12 & A-12352 & 0,42 & 0,03 & 0,30 & $<0,1$ & 0,16 & 44,67 & 99,23 \\
\hline 13 & A-12352* & 0,22 & 0,03 & 0,31 & $<0,1$ & - & 44,97 & 99,51 \\
\hline 14 & A-13478 & 0,09 & 0,10 & 0,17 & 0,11 & 0,27 & 39,85 & 99,64 \\
\hline 15 & A-13479 & 0,22 & 0,03 & 0,14 & 0,12 & 0,29 & 47,63 & 100,02 \\
\hline 16 & $\mathrm{Br}_{\text {bog }}$ & - & - & 0,20 & 0,07 & 0,04 & 45,37 & 99,03 \\
\hline 17 & $\mathrm{Br}_{\text {bog }^{*}}$ & 0,25 & - & - & - & - & 44,54 & 100,00 \\
\hline
\end{tabular}

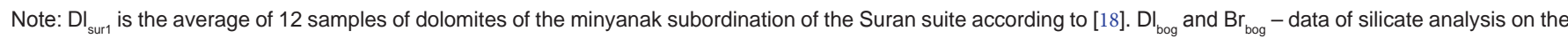
materials of the Abzelilovskaya GPP, $\mathrm{Br}_{\text {bog }}$ - well No. 7601, depth 23,0 m. Samples m662 - m675, A-12341-A-13479 - results of X-ray fluorescence analysis, author's materials. Samples m671a, m671b and A-12348 - data of silicate analysis, author's materials. Samples A-12350* and A-12352* - results of silicate analysis based on materials of A. A. Alekseev. Arr. $\mathrm{Br}_{\text {bog }}{ }^{*}-$ the average of the results of the silicate analysis of 4 samples, according to A. G. Potekhin. Dash - no data.

\section{Discussion and conclusions}

The presented materials show that in the southern part of the BMA in the meridionally elongated zone represented by carbonate rocks of the Minyak subsuite of the Suran Suite, one can find magnesian-ferruginous metasomatites of the Bogryashka ore occurrence that resemble the ferruginous magnesites of the Ismakaevo deposit located northward in the same subsuite. However, the metasomatites of Bogryashka differ by a variable polymineral composition, varying in amounts of ferrous magnesite, ferruginous dolomite, pyrite, quartz and, to a lesser extent, muscovite and chlorite. The distribution of lanthanides allows us to see certain similarities with the metasomatic carbonate rocks of the Ismakaevo deposit. The first type of REE distribution in the relatively monomineral magnesite of the ore occurrence (sample A-13479, see Fig. 3) is very similar to the typical magnesites of the Ismakaevo deposit (see Fig. 2). Unfortunately, in the last (3) type of distribution there are both essentially dolomite and essentially magnesite, as well as mixed, bimineral probes, therefore it is impossible associate the formation of the breinerite metasomatites with the exact type of process. Probably, here we see an intermediate picture of the distribution of lanthanides during the development of the metasomatic process.

The authors should note that even in the Ismakaevo deposit, the REE fractionation process is not as clear as, for example, in the
Satka deposit, where in coarse-crystalline magnesites one can observe the "inverted" trend of a gradual increase in the concentration of lanthanides normalized to chondrite from $\mathrm{La}$ to $\mathrm{Lu}$ [8]. The authors explain it by the fact that during the metasomatic crystallization of magnesite, the crystal lattice of the carbonate undergoes complete restructuralisation and the isomorphically inbound lanthanides adapt to the new conditions of existence. The effective ionic radius of $\mathrm{Ca}^{2+}$ is 1.1 angstroms and is close to the radius of lanthanum, while the ionic radius of $\mathrm{Mg}^{2+}$ is about 0.95 angstroms, which is close to heavy lanthanides and, above all, to lutetium [19]. Thus, in metasomatic recrystallization ideally one should manage the mineralogical control of the REE distribution depending on the carbonate matrix: Ca-containing minerals have a trend of distribution of the type $\mathrm{La}>\mathrm{Lu}$, while minerals with cations of lesser ionic radius (magnesite, siderite, rhodochrosite) have a trend of distribution $\mathrm{La}<\mathrm{Lu}$.

A separate question is the explanation of the "roof-like" form of the REE distribution with the enrichment of the lanthanides of the middle group, noted for the wallrock dolomites (which in fact are also bimineral formations - dolomites with an admixture of magnesite crystals [7]). A partial explanation of this effect can be that in metasomatites having (3) type of distribution, relative removal of light lanthanides (La-Nd), associated with mineralogical control, occurred, since in the metasomatic formation of magnesite, light REEs are easier to 
Table 3. Correlation coefficients of the microelements concentration with the mineral composition of carbonate metasomatites.

\begin{tabular}{|c|c|c|c|c|c|c|c|c|c|c|c|}
\hline № & Mgz & Dol & Py & $Q$ & Ms & № & $\mathrm{Mgz}$ & Dol & Py & $Q$ & Ms \\
\hline $\mathrm{Li}$ & 0,22 & $-0,29$ & $-0,47$ & 0,76 & 0,71 & La & $-0,18$ & 0,01 & 0,12 & 0,38 & 0,38 \\
\hline $\mathrm{Be}$ & 0,39 & $-0,42$ & $-0,50$ & 0,83 & 0,80 & $\mathrm{Ce}$ & $-0,17$ & 0,01 & 0,08 & 0,35 & 0,38 \\
\hline $\mathrm{Sc}$ & 0,05 & $-0,23$ & $-0,04$ & 0,28 & 0,20 & $\mathrm{Pr}$ & $-0,19$ & 0,04 & 0,07 & 0,26 & 0,32 \\
\hline $\mathrm{Ti}$ & 0,20 & $-0,34$ & $-0,30$ & 0,77 & 0,58 & $\mathrm{Nd}$ & $-0,28$ & 0,15 & 0,04 & 0,14 & 0,22 \\
\hline $\mathrm{V}$ & 0,07 & $-0,24$ & $-0,21$ & 0,59 & 0,53 & $\mathrm{Sm}$ & $-0,55$ & 0,59 & 0,03 & $-0,42$ & $-0,35$ \\
\hline $\mathrm{Cr}$ & $-0,16$ & $-0,00$ & 0,34 & $-0,08$ & $-0,08$ & $\mathrm{Eu}$ & $-0,53$ & 0,60 & 0,02 & $-0,46$ & $-0,40$ \\
\hline $\mathrm{Mn}$ & 0,43 & $-0,27$ & $-0,21$ & $-0,39$ & $-0,18$ & $\mathrm{Gd}$ & $-0,56$ & 0,62 & 0,08 & $-0,49$ & $-0,43$ \\
\hline $\mathrm{Fe}$ & 0,17 & $-0,31$ & 0,72 & $-0,45$ & $-0,29$ & $\mathrm{~Tb}$ & $-0,52$ & 0,60 & 0,03 & $-0,49$ & $-0,45$ \\
\hline Co & $-0,14$ & $-0,13$ & 0,82 & $-0,29$ & $-0,28$ & Dy & $-0,49$ & 0,57 & 0,01 & $-0,50$ & $-0,46$ \\
\hline $\mathrm{Ni}$ & $-0,10$ & $-0,16$ & 0,90 & $-0,35$ & $-0,30$ & $\mathrm{Ho}$ & $-0,46$ & 0,54 & $-0,00$ & $-0,51$ & $-0,47$ \\
\hline $\mathrm{Cu}$ & $-0,19$ & $-0,03$ & 0,88 & $-0,29$ & $-0,28$ & $\mathrm{Er}$ & $-0,43$ & 0,52 & $-0,03$ & $-0,50$ & $-0,45$ \\
\hline $\mathrm{Zn}$ & 0,20 & $-0,32$ & 0,48 & $-0,26$ & $-0,10$ & $\mathrm{Tm}$ & $-0,37$ & 0,46 & $-0,06$ & $-0,51$ & $-0,45$ \\
\hline $\mathrm{Ga}$ & 0,39 & $-0,55$ & $-0,22$ & 0,58 & 0,74 & $\mathrm{Yb}$ & $-0,33$ & 0,45 & $-0,10$ & $-0,49$ & $-0,43$ \\
\hline $\mathrm{Ge}$ & 0,36 & $-0,56$ & 0,15 & 0,57 & 0,66 & $\mathrm{Lu}$ & $-0,27$ & 0,38 & $-0,11$ & $-0,50$ & $-0,45$ \\
\hline As & 0,24 & $-0,17$ & $-0,04$ & $-0,21$ & $-0,19$ & $\mathrm{Hf}$ & 0,14 & $-0,34$ & $-0,21$ & 0,66 & 0,57 \\
\hline Se & $-0,48$ & 0,39 & 0,41 & $-0,46$ & $-0,46$ & $\mathrm{Ta}$ & 0,27 & $-0,33$ & $-0,27$ & 0,19 & 0,11 \\
\hline $\mathrm{Rb}$ & 0,32 & $-0,43$ & $-0,36$ & 0,79 & 0,84 & W & $-0,25$ & $-0,06$ & 0,51 & $-0,15$ & $-0,13$ \\
\hline $\mathrm{Sr}$ & $-0,41$ & 0,46 & 0,22 & $-0,51$ & $-0,54$ & $\mathrm{TI}$ & $-0,31$ & $-0,01$ & 0,68 & $-0,24$ & $-0,23$ \\
\hline$Y$ & $-0,46$ & 0,55 & $-0,00$ & $-0,51$ & $-0,46$ & $\mathrm{~Pb}$ & $-0,19$ & $-0,06$ & 0,80 & $-0,26$ & $-0,24$ \\
\hline $\mathrm{Zr}$ & 0,18 & $-0,39$ & $-0,16$ & 0,69 & 0,60 & $\mathrm{Bi}$ & $-0,19$ & $-0,06$ & 0,81 & $-0,24$ & $-0,21$ \\
\hline $\mathrm{Nb}$ & 0,29 & $-0,40$ & $-0,31$ & 0,56 & 0,45 & $\mathrm{Th}$ & $-0,21$ & $-0,01$ & 0,30 & 0,06 & 0,01 \\
\hline Mo & $-0,28$ & $-0,01$ & 0,53 & $-0,22$ & $-0,20$ & U & $-0,31$ & 0,07 & 0,06 & 0,45 & 0,07 \\
\hline $\mathrm{Ag}$ & $-0,06$ & $-0,11$ & 0,82 & $-0,31$ & $-0,28$ & $\mathrm{Sb}$ & $-0,17$ & $-0,05$ & 0,90 & $-0,28$ & $-0,26$ \\
\hline $\mathrm{Cd}$ & $-0,33$ & 0,17 & 0,48 & $-0,35$ & $-0,31$ & $\mathrm{Cs}$ & 0,28 & $-0,43$ & 0,11 & 0,46 & 0,76 \\
\hline Sn & $-0,27$ & 0,13 & 0,36 & $-0,15$ & $-0,17$ & $\mathrm{Ba}$ & $-0,16$ & $-0,10$ & 0,66 & $-0,17$ & $-0,14$ \\
\hline
\end{tabular}

Note: Mgz - magnesite, Dol - dolomite, Py - pyrite, Q - quartz, Ms - muscovite; the values in bold and italic are the ones with the correlation coefficients that are more than 0.3 .

remove than heavy ones. However, one can observe some enrichment with lanthanides of the middle group, strongest in the wallrock dolomites of the Ismakaevo deposit, but also occurring among the metasomatites of Bogryashka.

Comparison of some features of the distribution of REE in the metasomatites of the Ismakaevo deposit and the ore occurrence of Bogryashka (Table 4) shows that in magnesites and dolomites of both objects, the REE amounts are similar (10-14 g/t). However, the wallrock dolomites of the Ismakaevo deposit that contain an admixture of magnesite, in which the sum of REE increases (on average to 73 $\mathrm{g} / \mathrm{t}$ ), differ sharply. The $\mathrm{Y} / \mathrm{Ho}$ ratio in both objects is low, relative to the sedimentary carbonate rocks and magnesites of the Satka deposits (about 50 [8]), and indicates a significant distance of fluid migration in the Avzyan ore region. The value of the normalized ratio of light to heavy REE also behaves uniformly in both objects, decreasing in magnesite relative to the enclosing dolomites. In the wallrock dolomites of Ismakaevo and, especially, in the metasomatites of the (3) distribution type in Bogryashka, it has the minimal values, indicating the maximum fractionation of lanthanides in metasomatic recrystallization, associated with the relative removal of light lanthanides. In principle, the ratio $\mathrm{Ce} / \mathrm{La}>1$, noted in almost all the groups of examined metasomatites also indicates this. Weak positive values of the cerium anomaly in almost all the examined groups and metasomatite samples can confirm the sharply reducing nature of the fluids. This is probably also evidenced by a small positive europium anomaly, as well as widespread development of pyrite in metasomatites. Authors also note that in the sedimentary carbonate rocks of Riphean, as in most other sedimentary rocks, one can observe a noticeable negative anomaly of europium. As a rule, metasomatic formations inherit it too, except for special cases associated with the high-temperature nature of the fluids (for example, in contact zones with dikes of basic composition [8]) or with a dramatically reducing conditions of metasomatism, in which europium passes from trivalent to divalent state, sharply increases the ionic radius and comparatively easily accumulates in the dolomite [20].

The fractionation of REE can also manifest depending on the properties of the fluid. If enrichment with various ligands (complexing agents such as $\mathrm{H}_{2} \mathrm{O}, \mathrm{F}, \mathrm{Cl}$ ) occurs and the basicity of fluids rises sharply, hydrothermal redeposition more actively affects the lanthanides of the middle and heavy group [21]. Such conditions often arise in long-term functioning hydrothermal systems that have experienced intensive interaction with host rocks and have the evolved composition at which the initially ionic solutions with high acidity were converted into fluids with more basic properties. Such fluids often occur during remobilization and lead to an increase in the role of heavy lanthanides in the composition of metasomatic products [20]. The data of the $\mathrm{Sr}-\mathrm{Nd}$ systematics of Ismakayevo magnesites confirms the crustal composition of the fluids responsible for metasomatic rock transformations (the values of epsilon $\mathrm{Nd}_{(1250)}$ in magnesites are from -11.3 to -9.0 , which is even lower than the values of epsilon $\mathrm{Nd}_{(1550)}$ in the enclosing limestones of the Minyak subsuite -6.4), which implies a prolonged and intensive interaction of fluids with rocks of the Riphean section [11].

One can observe a similar pattern in the Suran fluorite deposit located in the north of the same structural and formation zone as

Table 4. Geochemical modules of REE distribution in carbonate metasomatites.

\begin{tabular}{|c|c|c|c|c|c|c|c|c|}
\hline \multirow{2}{*}{ Module } & \multicolumn{4}{|c|}{ Ismakayevo deposit } & \multicolumn{4}{|c|}{ Bogryashka manifestation } \\
\hline & Cal & Dol-host & Dol-Ore & Mgz & A-13478 Dol & A-13479 Mgz & $\mathrm{Dol}+\mathrm{Mgz}(2)$ & $\mathrm{Dol}+\mathrm{Mgz}(3)$ \\
\hline$n$ & 3 & 11 & 6 & 19 & 1 & 1 & 4 & 10 \\
\hline$\Sigma$ REE & 41,22 & 14,05 & 72,59 & 10,15 & 9,05 & 10,06 & 14,21 & 13,63 \\
\hline $\mathrm{Y} / \mathrm{Ho}$ & 35 & 30 & 26 & 24 & 31,78 & 34,31 & 24,72 & 26,99 \\
\hline$(\mathrm{LLn} / \mathrm{HLn}) \mathrm{N}_{\mathrm{C} 1}$ & 6,9 & 7,08 & 2,35 & 2,89 & 6,25 & 4,40 & 5,69 & 0,67 \\
\hline $\mathrm{Ce} / \mathrm{Ce}^{*}$ & 1,06 & 1,01 & 1,28 & 1,03 & 1,03 & 1,16 & 1,04 & 0,89 \\
\hline $\mathrm{Ce}_{\mathrm{C} 1} / \mathrm{La}_{\mathrm{C} 1}$ & 0,74 & 0,76 & 1,86 & 1,01 & 0,74 & 1,24 & 0,80 & 1,05 \\
\hline $\mathrm{Eu} / \mathrm{Eu}^{*}$ & 0,84 & 0,82 & 1 & 1,17 & 0,84 & 1,03 & 0,89 & 0,95 \\
\hline
\end{tabular}

Note: Cal - camstone (limestone); Dol-host - hosting dolomite; Dol-Ore - near-ore dolomite; Mgz - magnesite; (2) and (3) are the types of REE distribution in car-

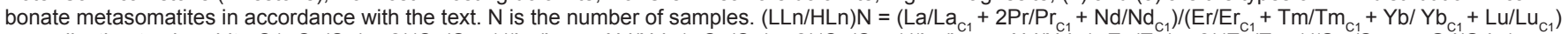

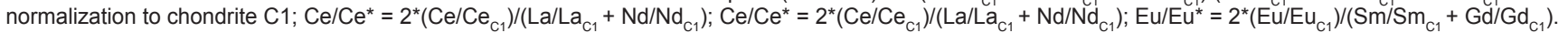



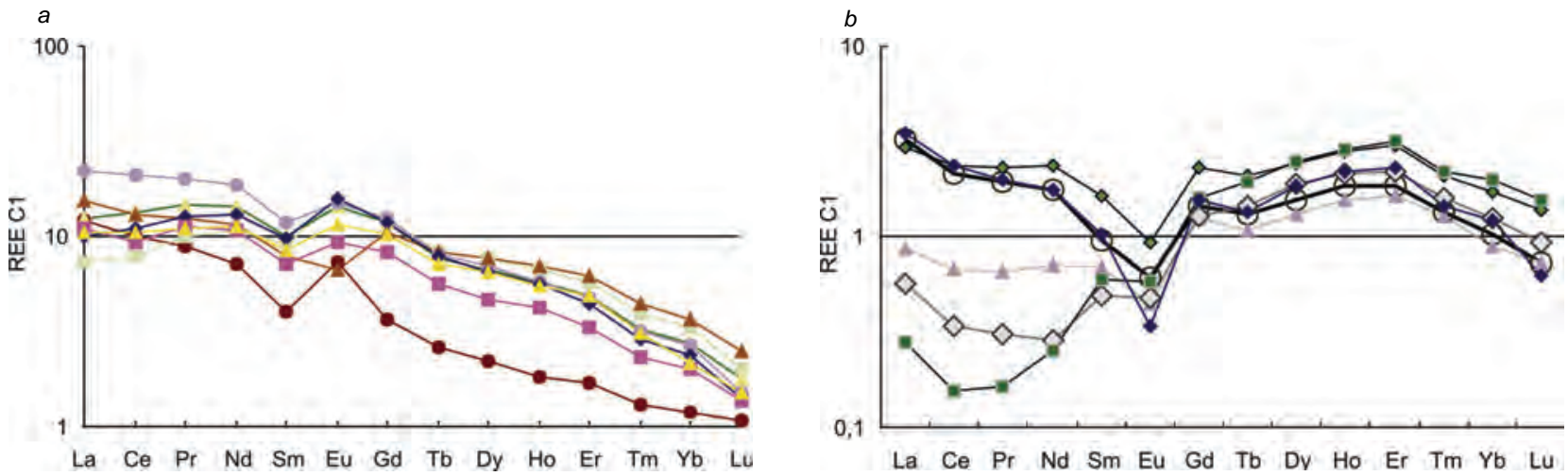

Figure 5. Chondrite-normalized (C1) distribution of REE in the fluorites of the Suran deposit. $a-$ porcelain and violet fluorites of the first generation; $b-$ optical redeposited metasomatic fluorites of the last generation (remobilization) (according to [12, 22]).

the considered metasomatic objects. Fluorites in this deposit are of several types (Fig. 5), with the first-time violet fluorites and selaites having entirely typical labels for the distribution of REE for Ca-containing minerals $(\mathrm{La}>\mathrm{Lu})$, metasomatically superimposed with green granitoid-type fluorites with increased concentrations of REE and subhorizontal distribution. The last by the age relationships are optical fluorites, in which the REE distribution is mirror-deployed in relation to the first types, what is precisely the result of remobilization [22]. For all types of fluorites, the authors obtained an errorchron with an age of $1219 \pm 120 \mathrm{Ma}$. That is, we observe extended in a certain time evolutionary process of the hydrothermal system that developed in the same area, $20 \mathrm{~km}$ to the north of Ismakaevo village in the same Suran Suite west of the Mashak graben, in the same formation zone. As already mentioned, the age of the Ismakaevo magnesite deposit, according to Sm-Nd systematic data, is $1250 \pm 130 \mathrm{Ma}$. It is indicative that in optical fluorites, the rise in REE values begins with samarium "roof-like distribution," the maximum of which falls on gadolinium in complete analogy with the distribution (3) for the breinerites of Bogryashka.

In addition, we can note the similarity of the isotope composition of sulfur pyrite and chalcopyrite, found in the form of impregnation in the Suran fluorites and pyrites of the predominant generation in magnesian-ferruginous metasomatites on the ore occurrence of Bogryash$\mathrm{ka}$. According to our data, sulfides from fluorites, as well as pyrite from the breynerites, are considerably enriched with the ${ }^{34} \mathrm{~S}$ isotope. Their values of $\delta^{34} S$ form an interval of approximately 26 to $34 \%$, which indicates an evaporitic source of sulfur in the formation of sulfides [23].

Therefore, the authors revealed a certain similarity of the mineral composition of the carbonate metasomatites of the Ismakaevo magnesite deposit and the ore ore occurrence of Bogryashka, as well as similar features of distribution of REE in them and in the Suran fluorite deposit. We can assume that all three objects located in the same stratigraphic subdivision and within the same structural-formational zone in the western side of the Mashak graben are associated with a single process of fluid generation. The fluid, judging from the data of studying $\mathrm{Cl}-\mathrm{Br}$ systematics and microcryometry of fluid inclusions $[12,13]$, and the isotopic data of sulfur, were the buried evaporite solutions that experienced intensive interaction with sedimentary and volcanic rocks in the tectonically active zone of the Mashak riftogenic graben. The effect of the fluid on the host rocks led to active metasomatism in the carbonate rocks of the Suran Suite.

The authors are grateful to N. V. Cherednichenko and D. V. Kiseleva (IGG UB RAS) for conducting ICP-MS analyzes.

\section{REFERENCES}

1. Maslov A. V., Krupenin M. T., Gareev E. Z., Anfimov L. V. 2001, Rifey zapadnogo sklona Yuzhnogo Urala (klassicheskie razrezy, sedimento- $i$ litogenez, minerageniya, geologicheskie pamyatniki prirody) [Riphean of the western slope of the Southern Urals (classical sections, sedimento- and lithogenesis, mineralogy, geological monuments of nature)], Ekaterinburg, vol. 1, $352 \mathrm{c}$.

2. Rosenberg P. E. 1963, Synthetic solid solutions in the systems $\mathrm{MgCO}_{3}-\mathrm{FeCO}$ and $\mathrm{MnCO}_{-}-\mathrm{FeCO}$. American Mineralogist, vol. 48, no. 11/12, pp. 1396-1400.

3. Demchuk I. G. 1981, Rentgenostrukturnoe issledovanie zhelezistykh dolomitov iz nizhnego rifeya na Yuzhnom Urale [X-ray diffraction study of ferruginous dolomites from the Lower Riphean in the Southern Urals]. Ezhegodnik-1980 IGG UNTS AN SSSR [Yearbook-1980 IG of the USSR Academy of Sciences], pp. 131-132.

4. Tsvetkov A. I., Valishikhina E. P., Piloyan G. O. 1964, Differentsial'nyy termicheskiy analiz karbonatnykh porod [Differential thermal analysis of carbonate rocks], Moscow, $166 \mathrm{p}$.

5. Larionov N. N. 2003, Gosudarstvennaya geologicheskaya karta Rossiyskoy Federatsii masshtaba 1:200 000. Yuzhno-Ural'skaya seriya. List N-40-XXII (Tukan) [State geological map of the Russian Federation at a scale of 1: 200000. South Ural series. Sheet N-40-XXII (Tukan)].

6. Shevelev A. I., Zuev L. V., Fedorov V. P. 2003, Mineral'no-syr'evaya baza magnezita i brusita Rossii [Mineral and raw materials base of magnesite and brucite of Russia], Kazan', 161 p.

7. Krupenin M. T., Kotlyarov V. A., Gulyaeva T. Ya., Petrishcheva V. G. 2008, Stadiynost' magnezial'nogo metasomatoza $v$ razlichnykh tipakh magnezitovykh mestorozhdeniy Yuzhno-Ural'skoy provintsii (po dannym mikroanaliza) [Stages of magnesian metasomatism in various types of sparry magnesite deposits in the South Ural province (according to microanalysis)]. Litosfera [Litosfera], no. 3, pp. 98-120.

8. Krupenin M. T. 2005, Geologo-geokhimicheskie tipy i sistematika RZE mestorozhdeniy Yuzhno-Ural'skoy magnezitovoy provintsii [Geological-Geochemical Types and REE Systematic of the South Ural Sparry Magnesite Province ]. Doklady RAN [Doklady Earth Sciences], vol. 405, no. 2, pp. 243-246.

9. Bau M., 1996, Control of the fractionation of isovalent trace elements in magmatic and aqueous systems: evidence from $\mathrm{Y} / \mathrm{Ho}, \mathrm{Zr} / \mathrm{Hf}$, and lanthanide tetrad effect. Contribution of Mineralogy and Petrology, vol. 123, pp. 323-333.

10. Maslov A. V., Ronkin Yu. L., Krupenin M. T., Gareev E. Z., Lepekhina O. P. 2003 Istochniki snosa rifeyskikh basseynov sedimentatsii oblasti sochleneniya Russkoy platformy i Yuzhnogo Urala: sintez petrograficheskikh, petro- i geokhimicheskikh dan$n y k h$ [Provenances of Riphean sedimentary basins at the Russian Platform-Southern Urals junction: Evidence from petrographic, petrochemical, and geochemical data] Doklady RAN [Doklady Earth Sciences], vol. 39, no. 2, pp. 219-222.

11. Krupenin M. T., Kuznetsov A.B., Konstatinova G. V. 2014, RZE i Sr-Nd sistematika kristallicheskikh magnezitov $i$ vmeshchayushchikh karbonatnykh porod Ismakaevskogo mestorozhdeniya, Yuzhnyy Ural [REE and Sr-Nd systematics of crystalline magnesites and host carbonate rocks of the Ismakaevo deposit, Southern Ural]. Problemy mineralogii, petrografii i metallogenii. Nauchnye chteniya pamyati P. N. Chirvinskogo [Problems of mineralogy, petrography and metallogeny. Scientific readings in the memory of P. N. Chirvinsky], no. 17, pp. 239-248.

12. Krupenin M. T., Prochaska V., Ronkin Yu. L. 2012, Stadiynost' obrazovaniya flyuoritov mestorozhdeniya Suran (Bashkirskiy megantiklinoriy) po dannym izucheniya lantanoidov, flyuidnykh vklyucheniy i Sr-Nd sistematiki [Stages of fluorite development in the Suran deposit (Bashkirian meganticlyne, Russia) according to the study of REE, fluid inclusions and Sr-Nd systematics]. Litosfera [Litosfera], no. 5, pp. 126-144.

13. Krupenin M. T., Garaeva A. A. 2015, Istochniki flyuidov dlya metasomaticheskikh magnezitov Ismakaevskogo mestorozhdeniya Yuzhno-Ural'skoy provintsi (termokriometriya flyuidnykh vklyucheniy) [Sources of fluids for metasomatic magnesite of Ismakaevo deposit in the Southern Urals province (microtermometry of fluid inclusions)]. Litosfera [Litosfera], no. 2, pp. 120-134.

14. Alekseev A. A., Alekseeva G. V., Kovalev S. G. 2003, Differentsirovannye intruzii zapadnogo sklona Urala [Differentiated intrusions of the western slope of the Urals], Ufa, $171 \mathrm{p}$.

15. Puchkov V. N. 2010, Geologiya Urala i Priural'ya (aktual'nye voprosy stratigrafii, tektoniki, geodinamiki i metallogenii) [Geology of the Urals and the Cis-Urals (actual issues of stratigraphy, tectonics, geodynamics and metallogeny)]. Ufa, 280 p. 
16. Musina A. M., Michurin S. V., Biktimerova Z. R., Kanipova Z. A. 2015, Khlor $\checkmark$ karbonatnykh porodakh rifeya Bashkirskogo megantiklinoriya [Chlorine in the carbonate rocks of the Riphean of the Bashkir meganticlinorium]. Materialy III Vserossiyskoy molodezhnoy geologicheskoy konferentsii [Materials of the third All-Russian Youth Geological Conference], Ufa, pp. 144-149.

17. Michurin S. V., Sharipova A. A. 2015, Izotopno-geokhimicheskie osobennosti rudoproyavleniya zolota Bogryashka (Yuzhnyy Ural) [Isotope-geochemical features of the gold ore occurrence Bogryashka (South Urals)]. Geologicheskiy sbornik [Geological digest], no. 12, pp. 144-158.

18. Anfimov L. V. 1997, Litogenez v rifeyskikh osadochnykh tolshchakh Bashkirskogo megantiklinoriya (Yuzhnyy Ural) [Lithogenesis in the Riphean sedimentary strata of the Bashkir meganticlinorium (Southern Urals)], Ekaterinburg, 290 p.

19. Shannon R. D. 1976, Revised effective ionic radii and systematic studies of interatomic distances in halides and chalcogenides. Acta Crystallogr. Sect., no. 32, pp. 751-767.

\section{Михаил Тихонович Крупенин,}

Krupenin@igg.uran.ru

Тамара Яковлевна Гуляева,

Валентина Георгиевна Петрищева

Институт геологии и геохимии УрО РАН

Россия, Екатеринбург, ул. Академика Вонсовского, 15

\section{Сергей Васильевич Мичурин,}

s michurin@mail.ru

Айсылу Азатовна Шарипова

Институт геологии Уфимского научного центра РАН

Россия, Республика Башкортостан,

Уфа, ул. Карла Маркса, 16/2
20. Bau M., Moeller P. 1992, Rare earth element fractionation in metamorphogenic hydrothermal calcite, magnesite and siderite. Mineralogy and Petrology, vol. 45, pp. 231-246.

21. Bau M. 1991, Rare-earth element mobility during hydrothermal and metamorphic fluid-rock interaction and the significance of the oxidation state of europium. Chemical Geology, vol. 93, pp. 219-230.

22. Krupenin M. T., Meller P., Dul'ski P. 1999, Redkozemel'nye i malye elementy vo flyuoritakh $i$ vmeshchayushchikh dolomitakh (nizhniy rifey, Yuzhnyy Ural) [Rare-earth and small elements in fluorites and host dolomites (Lower Riphean, Southern Urals)]. Geokhimiya [Geochemistry International], no. 11, pp. 11651177.

23. Michurin S. V., Kovalev S. G., Gorozhanin V. M. 2009, Genezis sul'fatov $i$ sul'fidov v nizhnerifeyskikh otlozheniyakh Kamsko-Bel'skogo avlakogena i Bashkirskogo megantiklinoriya [Genesis of sulfates and sulfides in the Lower Riphean deposits of the Kamsko-Belsk aulacogene and the Bashkir meganticlinorium], Ufa, 192 p.

Mikhail Tikhonovich Krupenin,

Krupenin@igg.uran.ru

Tamara Yakovlevna Gulyaeva,

Valentina Georgievna Petrishcheva,

Institute of Geology and Geochemistry of the Ural Branch

of the Russian Academy of Sciences

Ekaterinburg, Russia

Sergey Vasil'evich Michurin,

s_michurin@mail.ru

Aìsylu Azatovna Sharipova

Institute of Geology of Ufa Science Centre of the Russian Academy of Sciences

Ufa, Russia 